\title{
Surfactant protein DNA methylation: A new entrant in the field of lung cancer diagnostics? (Review)
}

\author{
MUDIT VAID ${ }^{1}$ and JOANNA FLOROS ${ }^{1,2}$ \\ ${ }^{1}$ The Penn State Center for Host-defense, Inflammation and Lung Disease \\ (CHILD) Research, Department of Pediatrics, ${ }^{2}$ Department of Obstetrics and \\ Gynecology, Penn State Hershey College of Medicine, Hershey, PA 17033, USA
}

Received August 22, 2008; Accepted September 25, 2008

DOI: 10.3892/or_00000182

\begin{abstract}
Lung cancer is a major cause of cancer-related mortality in both men and women. A 5-year survival of lung cancer patients is only $15 \%$ with a negative correlation between progressively advanced lung cancer stage and a 5-year survival period. The only chance for cure is surgical resection if done at the early stage of the disease. Therefore, an early diagnosis and a better prediction of prognosis could decrease mortality. An early diagnosis could provide the opportunity for a therapeutic intervention early in the course of the disease. Genetic alterations in the cancer genome include aneuploidy, deletions and amplifications of chromosomal regions, loss of heterozygosity $(\mathrm{LOH})$, microsatellite alterations, point mutations and aberrant promoter methylation. Of the various types of genetic alterations (i.e. gene amplifications, allele deletions, point mutations or deletions and methylation) reported in different tumor types, aberrant promoter methylation of genes is recent and is the focus of the present review. Specifically, we will briefly review the role of promoter methylation in various malignancies and then focus on lung cancer diagnosis and promoter gene methylation with emphasis on the methylation status of genes of the innate host defense, namely the surfactant proteins A and D.
\end{abstract}

Correspondence to: Dr Joanna Floros, Department of Pediatrics, H085, Penn State Hershey College of Medicine, 500 University Drive, Hershey, PA 17033, USA

E-mail: jfloros@psu.edu

Abbreviations: CGH, comparative genomic hybridization; LOH, loss of heterozygosity; NSCLC, non-small cell lung carcinoma; SCLC, small cell lung cancinoma; SCC, squamous cell carcinoma; SPs, surfactant proteins; SP-A, surfactant protein A; SP-B, surfactant protein B; SP-C, surfactant protein C; SP-D, surfactant protein $\mathrm{D}$; uPA, urokinase type plasminogen activator

Key words: CpG island, diagnosis, DNA methylation, human lung surfactant protein $\mathrm{A}$, human lung surfactant protein $\mathrm{D}$, lung cancer

\section{Contents}

1. Lung cancer prevalence and current status

2. DNA methylation

3. DNA methylation in malignancies other than lung cancer

4. Lung cancer and DNA methylation

5. SP-A and SP-D in lung cancer

6. Methylation signatures in SPs

7. Summary and expert opinion

\section{Lung cancer prevalence and current status}

Lung cancer is a major cause of cancer-related mortality in both men and women in industrialized countries and causes more deaths than colorectal, breast and prostate cancer combined $(1,2)$. The overall annual incidence and mortality rate of lung cancer has been estimated to be $\sim 104$ million new cases per year and 921,000 deaths in the world, with the highest rates currently observed in Europe and North America $(3,4)$. The incidence and mortality rates are higher for men than for women. However, lung cancer mortality has increased markedly among women since 1960, following an increased prevalence of smoking (5). A high degree of correlation between smoking and lung cancer has been observed. Smoking accounts for $80 \%$ of the attributed risk among men and for $45 \%$ of the cases among women (6).

The 5-year survival of lung cancer patients is only $15 \%$, which is much lower than the survival rate of colorectal (41\%) and breast $(67 \%)$ cancers. This is largely due to the fact that three quarters of lung cancer patients are diagnosed when their disease has spread regionally or distantly (7). There are studies on negative correlation between a 5-year survival period and lung cancer stage (as per TNM classification, where $\mathrm{T}$ is characteristic of primary tumor, $\mathrm{N}$ is regional lymph node involvement and $\mathrm{M}$ is metastasis). A 5-year survival period has been reported as high as $60-70 \%$ following resection of stage I lung cancer, while a 5-year survival rate of lung cancer as low as $8-13 \%$ has been observed if treatment starts at stages III-IV (8). At present, the only chance of cure is surgical resection at the early stage of the disease, with better prognosis for small tumors compared to larger ones. Thus, an early diagnosis of lung cancer and prediction of patient's prognosis on the basis of clinical and genetic 
characteristics of tumor could potentially decrease lung cancer mortality by enabling earlier and more appropriate therapeutic intervention.

\section{DNA methylation}

DNA methylation mainly refers to methylation at cytosine residues located in dinucleotide $\mathrm{CpG}$ sites. The specifics relating to $\mathrm{CpG}$ dinucleotide location and methylation status have been reviewed previously (9-15). In brief, the $\mathrm{CpG}$ dinucleotide distribution in most of the genome is statistically lower than the expected frequency. However, in some genomic regions that mainly coincide with promoters or regions involved in gene regulation, the frequency of $\mathrm{CpG}$ dinucleotides is that of the expected value. These $\mathrm{C}+\mathrm{G}$ rich regions are termed $\mathrm{CpG}$ islands [reviewed in (16)]. In the human genome, the pattern of $\mathrm{CpG}$ methylation varies during development [reviewed in (11)]. For example, in the case of germ line-specific genes and certain tissue-specific genes, promoter regions are subject to methylation as part of normal developmental processes [reviewed in $(11,17)]$. This ensures that specific genes are expressed in specific tissues and at specific times of development. Methylation of regulatory regions is involved in genomic imprinting and $\mathrm{X}$ chromosome inactivation in females [reviewed in (18)]. In a healthy individual [reviewed in (11)] most $\mathrm{CpG}$ islands are unmethylated and associated genes are expressed. However, if $\mathrm{CpG}$ islands are located within genes expressed in a tissuespecific manner, it is possible that the $\mathrm{CpG}$ islands remain unmethylated while these genes are silent (11). The lone CpGs found throughout the rest of DNA (i.e. not in $\mathrm{CpG}$ islands) are mostly methylated (19).

DNA methylation acting via deregulated gene expression has been recognized as a key component of aging $(20,21)$ and various diseases (22). Although, initially reported in cancer, DNA methylation is now being appreciated as playing a role in neurological, cardiovascular and immunological pathologies as well. For example, there are studies of associations between aberrant promoter methylation of certain genes and hypertension (23), immunodeficiency syndromes (i.e. ICF, ATRX) and autoimmunity diseases (i.e. systemic lupus erythematosus, rheumatoid arthritis) $(24,25)$ and neurological disorders (i.e. Alzheimer's disease) $(22,26)$.

\section{DNA methylation in malignancies other than lung cancer}

The cancer genome is characterized by a general decline in methylated cytosine level (genomic hypomethylation) accompanied by a local CpG island hypermethylation $(27,28)$, with both processes leading to dysregulated gene expression. Genomic hypomethylation (29) and perhaps gene-specific CpG island hypomethylation (30-32) may lead to cancer via activation of proto-oncogenes, reactivation of transposable elements, loss of gene imprinting and hyperactivation of other genes (i.e. host defense genes, see below). On the other hand, when $\mathrm{CpG}$ islands are hypermethylated, the activity of regulatory proteins that promote transcription is restricted due to tightly packed nucleosomes (33). This often leads to suppression of gene expression of genes that affect tumor suppression, DNA repair and chromatin condensation. Tumor suppressor genes contain unmethylated $\mathrm{CpG}$ islands in their promoters that become methylated in various malignancies. Although, both of these processes (i.e. genomic hypomethylation and gene-specific promoter hypomethylation or hypermethylation) occur concurrently in cancer, thus far no relationship has been found between global genomic hypomethylation and local hypermethylation, indicating that these processes may be independent of each other (34).

Hypermethylation. DNA hypermethylation is a well established epigenetic alteration seen in various types of malignancies. A growing number of genes are being recognized that harbor dense methylation in normally unmethylated promoter $\mathrm{CpG}$ islands, with some of them common across different types of tumors. These include genes mainly involved in functions such as cell-cycle control and apoptosis (p14, p15, p16, Rb, DAPK), DNA repair (MGMT, hMLH1), adhesion and metastasis (CDH1, CDH13), biotransformation (GSTP1) and signal transduction (RARß and APC). For example, epigenetic silencing of glutathione S transferase (GSTP1) is the most common (>90\%) genetic alteration reported in prostate cancer. It can be used to accurately distinguish benign and malignant prostate lesions (35). A similar prevalence of methylation changes was shown for RARß gene. The methylation of RARß correlates with more advanced pathological stage and allows discrimination between neoplastic and non-neoplastic prostate tissue (this included high-grade prostatic intraepithelial neoplasias and benign prostate hyperplasia) (36). The combination of methylation analysis with histological tests resulted in detection of $97 \%$ of prostate adenocarcinoma cases in comparison with only $64 \%$ when a histological test alone was used (37). Furthermore, an analysis of the hypermethylation status of a panel of four genes, GSTP1, RARß, TIG1 and APC, could detect prostate carcinoma with $100 \%$ specificity. Similarly, hypermethylation of 3 or more genes from a panel of 5 genes (CDH13, HSPA2, MLH1, RASSF1A, SOCS2) was observed in endometrial cancer, while $91 \%$ of the controls showed hypermethylation of none or fewer than 3 genes (38). Hypermethylation of a gene panel consisting of RARß1, p16, p14, RASSF1A, DAPK, and GSTP1 was observed in breast cancer tissue compared to non-cancer breast tissue (39).

Hypomethylation. Genomic hypomethylation refers to loss of methylation at $\mathrm{CpG}$ sites located in intergenic and intronic DNA regions (global hypomethylation), as well as in promoters of specific genes (gene-specific hypomethylation). Global hypomethylation mainly affects repeat sequences and transposable elements. It often leads to cancer via chromosomal instability due to aberrant transcription and recombination, while localized hypomethylation often leads to increased expression of proto-oncogenes, growth factors, and genes, the protein products of which are involved in cancer cell proliferation, invasion and metastasis (40). There is substantial evidence of association of hypomethylation (whether at genome level or individual loci) with cancer. For example, satellite DNAs (juxta centromeric Sat2 and centromeric Sat $\alpha$ ) were found hypomethylated in ovarian samples with a direct correlation between stage of tumors and 
degree of hypomethylation $(41,42)$. Similarly repeat sequences Sat2, Sat $\alpha$ and SatR-1 were found to be hypomethylated in breast cancer $(43,44)$. Hypomethylation at L1, a younger subfamily of autonomous long interspersed nuclear elements, which are a type of non-LTR retrotransposons, was reported in hepatocellular carcinoma (45), tumors of bladder, head and neck (46) and various benign and malignant ovarian carcinomas (47). Evaluation of the methylation status of LINE-1 repetitive sequences in genomic DNA derived from microdissected samples from several human normal and neoplastic tissues revealed a greater percentage of hypomethylation at LINE-1 repetitive sequences in several cancer tissues including breast, colon, lung, head and neck, bladder, esophagus, liver, prostate and stomach than their normal tissue counterparts (46). Similarly, hypomethylation of tumor genes, such as urokinase type plasminogen activator (uPA), heparanase and S100A4 led to their increased expression in cancer cells. uPA $(48,49)$ and heparanase $(50)$ belong to a category of proteases produced by tumor cells that degrade extracellular matrix, while S100A4 is a calcium binding protein that regulates production of matrix-degrading enzymes. These enzymes are responsible for remodeling of the extracellular matrix and for an increase in tumor cell proliferation and motility (51). In summary, the available data indicate that a) a derangement of $\mathrm{CpG}$ methylation in the promoter of a variety of genes has been shown to associate with numerous cancers, including lung cancer and b) methylation markers of various genes have been shown to be useful in tissue-specific cancer diagnosis.

\section{Lung cancer and DNA methylation}

Lung cancer is a disease where both, environment and genetics play a role $(6,52-56)$. There are two main types of lung carcinomas: non-small cell lung carcinoma (NSCLC) and small cell lung carcinoma (SCLC) (57). SCLC is most often a centrally located tumor arising from bronchial epithelium. NSCLC constitute the majority of all lung cancers ( $85-90 \%)$ and are sub-classified into three main histological types: the squamous cell, which is linked to smoking and for the most part is found near the bronchus, the adenocarcinoma found in the outer lungs and the large cell carcinoma that can originate anywhere in the lung. Squamous cell cancer has at least one of three differentiating features that include individual cell keratinization, spherical keratinization, or intercellular cytoplasmic bridges. Adenocarcinomas are malignant tumors with tubular, acinar, or papillary growth patterns, and/or mucus production. Large cell carcinoma is characterized by large nuclei, prominent nucleoli, abundant cytoplasm and well defined cell borders.

Most lung cancers start in the lining of the bronchi. Carcinogenesis, starting from a normal cell to an invasive carcinoma, is a multistep process (58). Lung carcinoma is preceded by a premalignant lesion, such as hyperplasia, metaplasia, or dysplasia of the bronchial epithelium. The transition of a premalignant lesion to lung cancer is often accompanied by several genetic events (some of them are common between SCLC and NSCLC), such as alterations in the expression of proto-oncogenes and tumor suppressor genes (58) and perhaps of other genes (32). These changes include aneuploidy, deletions and amplifications of chromosomal regions, loss of heterozygosity $(\mathrm{LOH})$, microsatellite alterations, point mutations and aberrant promoter methylation. Of interest, several of these genetic changes (i.e. aberrant promoter methylation, chromosome deletions, aneuploidy, altered expression of oncogenes, tumor suppressor genes, and other) occur during the premalignant stage that leads to malignant tumor cells and as such these changes may be useful markers in early detection of lung cancer (59-64). This indicates that several of the molecular, genetic and epigenetic changes that lead to malignant tumor cells occur early in the process, and as such these changes may be useful markers in early diagnosis of cancer. In fact, there is a considerable effort to use these genetic alterations as molecular biomarkers for early cancer diagnosis by applying different approaches. An ideal tumor marker should be highly sensitive, tumor-specific, easy to handle, and inexpensive.

While previous efforts, to identify tumor markers, used screening for mutations, $\mathrm{LOH}$, and microsatellite alterations, more recent strategies concentrate on aberrant promoter methylation (65). This is mainly because of the following reasons: i) Aberrant promoter methylation of specific genes has been shown to be an early event in the pathogenesis of lung cancer. For example, in a rat model of lung carcinogenesis (59), $94 \%$ of adenocarcinomas induced by a tobacco-specific carcinogen 4-methylnitrosamino-1-(3-pyridyl)-1-butanone were hypermethylated at the pl6 gene promoter; most importantly, this methylation change was frequently detected in precursor lesions to the tumors, adenomas and hyperplastic lesions. The timing for $p 16$ methylation was recapitulated in human squamous cell carcinoma (SCC) (59), where the pl6 gene was coordinately methylated in $75 \%$ of carcinoma in situ lesions adjacent to SCCs harboring this change. Moreover, the frequency of this event increased during disease progression from basal cell hyperplasia (17\%) to squamous metaplasia (24\%) to carcinoma in situ (50\%) lesions. Similarly, aberrant methylation of the $\mathrm{p} 16$ and/or $\mathrm{O}^{6}$-methyl-guanine-DNA methyltransferase promoter was observed in DNA from sputum in $100 \%$ of patients with squamous cell lung carcinoma up to 3 years before clinical diagnosis (66). Collectively, these observations indicate that assessment of the prevalence of these methylation markers could be useful for prediction of a lifetime risk of developing lung cancer; ii) The methylation pattern of some genes correlates with clinicopathological characteristics of lung cancer patients. For example, lung cancer patients with methylated RASSF1A had an overall shorter survival than patients who had unmethylated RASSF1A (67). Similarly, a direct correlation has been reported between methylation of the APC and DAPK genes with poor survival rate in NSCLC patients $(68,69)$; iii) it is relatively easy to detect the methylation status quantitatively from a variety of samples ranging from, tumor sample to sputum to blood, of lung cancer patients (70). However, to date the penetrance of DNA methylation at any single locus has not been high enough to provide great clinical sensitivity.

A major focus of research in cancer diagnosis is to create a panel of methylation markers (rather than study methylation in a single gene) that could be used to detect cancer with high sensitivity and specificity. The first step in developing a panel of DNA methylation biomarkers is to identify patterns of 
tumor methylation signatures (71). One approach is a genomewide screening $(72,73)$, where, after identifying patterns or signatures of genomic changes in cancer tissues or cancer cell lines, candidate genes and/or regions can be selected to be included in the biomarker panel. Another one is the candidate gene approach, where selected tumor associated genes (such as tumor suppressor genes, proto-oncogenes, genes expressing cell cycle proteins, proteins involved in DNA repair, apoptosis, or host defense and other) are screened in samples of cancer tissue for their aberrant methylation. Using the candidate gene approach several genes have been described to be inactivated by promoter methylation in lung cancer, as previously reviewed $(74,75)$. A recent study exemplified the candidate gene approach along with high throughput technologies (76). Aberrant methylation was studied at 1536 specific CpG sites in 371 genes selected based on their biological relevance in lung cancers and normal lung tissues. The selected genes included tumor suppressor genes and oncogenes, genes that are indirectly involved in cancer development (i.e. DNA repair genes), metastasis-inhibitor genes, genes regulated by various signaling pathways, and/or responsible for altered cell growth, differentiation and apoptosis, genes considered to be targets for oncogenic transformation, genes of innate host defense including lung surfactant protein genes, imprinted genes and previously reported differentially methylated genes $(29,75,77)$.

Among the genes identified with this high throughput approach that showed an altered methylation pattern in lung cancer compared to normal lung tissue were the surfactant protein (SP) genes, SP-A and SP-D. These genes, in addition to their role in surfactant-related functions, have been shown to play important roles in the innate host defense of the lung and/or regulation of inflammatory processes. Since infections and ensuing inflammatory processes have been implicated in cancer pathogenesis (78-80), the surfactant proteins, given their physiological relevance in lung health, are good candidate genes for study in lung cancer and their methylation signatures may serve as valuable markers in lung cancer detection.

\section{SP-A and SP-D in lung cancer}

An essential for life function is carried out by the lung, namely the oxygen and carbon dioxide exchange, where the delicate gas-exchanging alveolar epithelium that lines the terminal lung airspaces allows for efficient diffusion of oxygen and carbon dioxide between inspired air and the pulmonary circulation. The lung via inspired air is virtually in direct contact with the external environment and therefore it is exposed daily to thousands of insults (i.e. bacteria, viruses, allergens, particulate matter, ozone and other) and yet under normal circumstances remains well functioning. A delicate network comprising of various immune cells (i.e. macrophages, neutrophils and other) and molecules of innate host defense together maintain a normal functioning lung via their ability to mount an appropriate inflammatory response to help get rid of foreign insulting agents. Inflammation under normal circumstances is self-limiting and it subsides as soon as foreign material is removed. However, an inappropriate response (whether less than optimum or more than optimum) can have a negative impact on lung structure and function. A suboptimal inflammatory response may lead to persistence or continuous presence of an infection or foreign matter in the lung, while an overzealous inflammation may take the form of chronic inflammation. Either scenario of deranged host defense results in cellular and/or tissue damage that may ultimately lead to lung cancer or other pulmonary diseases. The relationship between inflammation and lung cancer is not new. It was first proposed by Virchow in 1868, when he first observed leukocytes in neoplastic tissue (81). Since then several cancer types have been shown to associate with inflammation. Also, there is a growing body of evidence that many malignancies are initiated by infections (78-80). According to an estimate $>15 \%$ of malignancies can be attributed to infections (79).

Molecules of innate immunity and host defense in the lung include the surfactant proteins (SP-) A or SP-A and SP-D. $\mathrm{SP}-\mathrm{A}$ is a major protein component (by weight) of the lipoprotein complex called surfactant, which is essential in preventing, at low lung volumes, alveolar collapse via its ability to lower surface tension at the air-liquid interface in the terminal airspaces or alveoli. SP-D co-purifies with surfactant. SP-A and SP-D are hydrophillic proteins [reviewed in (82-85) and have been shown to play a role in surfactantrelated functions of the lung (i.e. surfactant homeostasis, structure, inhibition of surfactant secretion and other) as well as in host defense and/or the regulation of inflammatory processes in the lung. Both have been implicated in diverse activities of pulmonary host defense and regulation of inflammation via their effects on immune cells in the presence or absence of a pathogenic insult (86-93), production of reactive oxygen and nitrogen intermediates $(94,95)$, clearance of apoptotic cells (96-98) and other. Furthermore, both SP-A and SP-D have been shown to provide a link between innate and adaptive immunity $(99,100)$, via their effects on dendritic cells.

Study of the SP-A-/- mice has provided in vivo support of the role of SP-A in innate host defense. These mice lack tubular myelin, a structural form of surfactant, and although they are able to survive with no apparent pathology in a sterile environment (101) and respond similarly to wild-type mice following exercise or hyperoxic conditions (102), their pulmonary immune responses are insufficient during immune challenge $(103,104)$. SP-D-/- mice on the other hand although early in life appear healthy with no differences in the biophysical function of surfactant, later in life exhibit quite a complex phenotype. Even in the absence of any apparent insult, the SP-D-/- mice display phenotypic abnormalities in alveolar macrophages and type II epithelial cells, and increased lipid pools, indicating that SP-D has an important role in surfactant homeostasis $(101,105,106)$. Metalloproteinases are also elevated in their lungs. SP-D-/- lungs develop an emphysema-like phenotype (105). Therefore, collectively, given their role in infection and inflammation, alterations in the level or activity of lung collectins (SP-A and SP-D) may lead to pathogenesis of various diseases, including lung cancer.

In human, SP-D is a single gene locus, whereas the SP-A locus consists of two functional genes, SP-A1 and SP-A2 with several intragenic haplotypes or variants identified for each SP-A gene $(107,108)$. The in vitro expressed products of the SP-A1 and SP-A2 genes have been shown to exhibit different 
levels of activity in terms of their ability to modulate cytokine production by a macrophage-like cell line (109-111), enhance phagocytosis of bacteria by alveolar macrophages (112-114), inhibit secretion of surfactant by epithelial type II cells (115) and bind to carbohydrates (116). Given the observed differences in activity between SP-A1 and SP-A2, it is possible that the overall functional activity of SP-A in the lung depends on the relative functional content of each SP-A1 and SP-A2 product and that derangement in SP-A1 and/or SP-A2 expression or functional ability compromises lung health. In a recent study, we showed that the SP-A1 to total SP-A ratio, in samples of bronchoalveolar lavage from different individuals, differs as a function of lung health status and age (117). Moreover, both SP-A1 and SP-A2 genes have been identified with extensive genetic variability (107) that affects function and/or structure (110,112-116) or regulation (118-121). This extensive genetic variability may serve as 'tag' to identify individuals at disease risk and also provide insight into the underlying mechanisms of a given lung disease.

\section{Methylation signatures in SPs}

Although the study of methylation signatures of SPs in lung cancer is recent, the role of SPs in lung cancer has been under investigation for $>10$ years. Several studies based on different approaches including, reverse transcriptase PCR, immunoblot analysis, ELISA and immunohistochemical analysis have been carried out to study alterations of SP-A in lung cancer (122-128), while there is a single study (129) that has reported usefulness of SP-D as a diagnostic marker for lung cancer. Immunohistochemical detection of SP-A in lungs (130) and pleural effusions (131) has been reported to be useful for differential diagnosis of lung cancer from metastatic carcinomas to lung and pleural mesotheliomas.

Various genetic variants and/or epigenetic changes of SPs may under certain micro-environmental conditions, alter surfactant protein expression and/or function and these changes in turn may modulate susceptibility to lung cancer. Studies carried out by our group and others support this postulate. We have shown an association of lung cancer susceptibility with different SP-A variants (132) and a high resolution comparative genomic hybridization ( $\mathrm{CGH}$ ) analysis of a cDNA microarray showed deletion of the SP-A gene to be one of the most common genomic changes in primary lung cancer (133). The latter genomic aberrations were found to be associated with tumor progression and a history of smoking and were proposed as useful biomarkers in the identification of poor prognoses in patients with NSCLC (134). Recently, using a high-throughput technology platform, consisting of miniaturized bead-based array, we studied the methylation level of 1536 specific $\mathrm{CpG}$ sites in a panel of 371 genes (76). The panel included the lung surfactant protein genes, SP-A1, and SP-D, as well as the two hydrophobic surfactant protein genes, SP-B and SP-C, along with other genes documented to be involved in cancer and shown to be differentially methylated $(29,75,77)$ in cell lines, normal tissues, or lung biopsy cancer samples. This study led to identification of a panel of 55 methylation markers that included surfactant protein (SP-) methylation markers. With these markers, lung adenocarcinomas could be distinguished from normal lung tissues with high specificity (76).

With regard to SP gene methylation, a total of 4 groups were obtained, when the collective DNA methylation profile was assessed, by clustering analysis, for $11 \mathrm{CpG}$ sites of lung surfactant proteins (SP-A1, SP-B, SP-C and SP-D) in 23 adenocarcinoma tissues and 23 matched non-cancerous lung tissues obtained from the same patient (32). The percentage of cancer samples increased from group 1 to group 4, while the overall level of methylation for the SP markers tested decreased as one moved from group 1 to group 4. This indicated an inverse association of the collective level of methylation of the $11 \mathrm{SP}$ CpG sites with lung adenocarcinoma. A similar pattern was observed in the case of squamous cell carcinoma compared to matched control tissues obtained from the same patient, although the clustering was not as tightly defined. A further comparison of the methylation levels of each $\mathrm{CpG}$ site in cancerous and noncancerous samples revealed that from the $11 \mathrm{CpG}$ markers analyzed, only $4 \mathrm{CpG}$ sites (namely SP-A1_370, SPA1_1080, SP-D_1170, and SP-D_1370) differed significantly between cancerous and non-cancerous samples in both adenocarcinoma and squamous cell cancer cohorts, indicating that these $4 \mathrm{CpG}$ sites can serve as potential biomarkers for lung cancer diagnosis. Of interest, a better group separation was obtained when the methylation content of all 11 SP CpG sites were included in the analysis compared to that obtained with only the four $\mathrm{CpG}$ sites that showed significant differences between cancer and non-cancer tissues. Therefore, at this point, we can not exclude the possibility that inclusion of small changes in methylation of certain genes may help improve the specificity of methylation panels of genes identified with significant $\mathrm{CpG}$ changes.

A preliminary analysis of the impact of individual $\mathrm{CpG}$ methylation on gene expression revealed an inverse correlation (32) between the methylation content and mRNA expression for one of the SP-D CpGs (SP-D_1170). This CpG showed significant changes in methylation between cancer and normal lung tissue. An association between the methylation content of an SP-A1 CpG (SP-A1_1468 that did not show significant differences between cancer and normal tissue) and mRNA expression was also shown. These preliminary observations indicate that methylation of a given $\mathrm{CpG}$ site may be one of the mechanisms that regulates SP-A1 and SP-D expression. However, the details of the mechanisms via which an overexpression of SP-A and/or SP-D (presumably a result of promoter hypomethylation) may contribute to lung cancer development are currently unknown.

It is possible that SP-A and SP-D contribute to deranged immunity in cancer via their role on dendritic cell maturation $(99,100)$. Dendritic cells in lung tumor infiltrates appear to be largely defective regarding their ability to stimulate T-cells (135). The effect of SP-A and SP-D on dendritic cell maturation and/or activity appears to be in opposite direction $(99,100)$ indicating that together SP-A and SP-D provide under normal conditions the necessary balance required for a healthy immune lung response. Although hypomethylation at both SP-A1 and SP-D CpG sites was observed in lung cancer (32) and an association was shown between hypomethylation 
of certain $\mathrm{CpG}$ sites and SP expression, there is no information available to indicate whether the changes in expression are similar between SP-A1 and SP-D. Also information is lacking with regards to the role of SP-A2 CpG methylation in lung cancer. It is currently unknown whether any SP-A2 CpG sites are hyper- or hypomethylated and whether these associate with lung cancer. Moreover, as discussed above, SP-A1 and $\mathrm{SP}-\mathrm{A} 2$ exhibit differences in their ability to modulate macrophage function with regards to proinflammatory cytokine production $(92,109-111)$ and bacterial phagocytosis (112-114). Since the level of SP-A1 and SP-A2 differences on macrophage function depends on SP-A protein concentration and functional integrity, an altered SP-A expression or SP-A dysfunction, as it occurs after SP-A is exposed to ozone, may adversely affect macrophage host defense function. This may lead to an overall deranged lung host defense and perhaps lung cancer. Thus, although deranged SP-A and SP-D expression may adversely affect lung immunity via their effects on dendritic cells, macrophages, or other cells, our current knowledge is limited to further comment on this.

\section{Summary and expert opinion}

The available data are consistent with a potential contribution of SP-A in lung cancer. We postulate that a hyperactivity of SP-A via increased expression as it may occur via hypomethylation (32), or a decrease of SP-A activity as it may occur via SP-A dysfunction due, for example, to oxidation $(109,111,112)$, or lack of SP-A as it may occur by SP-A gene deletion (133) may contribute to lung cancer pathogenesis. An excessive SP-A activity may lead to an exuberant and sustained inflammatory reaction that may have dire consequences on lung tissue integrity. On the other hand, reduced SP-A activity or lack of SP-A activity may compromise the innate host defense ability of the lung to maintain a healthy lung status. In either case, where SP-A (and/or SP-D) over-functions or underfunctions, the host defense ability of the lung is compromised and with time and/or in the presence of various macro- or micro-environmental insults, this may contribute to lung carcinogenesis.

Although the role of innate host defense molecules, such as SP-A and SP-D, in cancer is still in its early stages, the available literature argues for an inclusion of SP-A and SP-D in future studies, where panels of methylation markers for early lung cancer diagnosis are being considered. The SPexample, discussed here, provides support for the role of inflammation in cancer development and as such there should be consideration of inclusion in panels of diagnostic markers of lung cancer, not only of SPs but also other innate host defense molecules.

In the pursuit of identifying the best panel(s) that would be appropriate for a given type of lung cancer, it is likely to encounter several challenges. These may not only relate to decisions as to which genes to include but may also relate to decisions as to what percent of methylation change should favor inclusion of a given gene. For example, small nonstatistically significant changes along with larger statistically significant changes may provide higher level of specificity.
Since environmental insults have been shown to contribute to lung cancer development, inclusion of genes responsive to such insults may also be warranted. Moreover, as we may move towards 'individualized medicine' selection of a panel of markers for diagnostic use, may require prior understanding of the individual's life style. Such a knowledge may help determine which gene-environment interactions are more relevant to that individual and consequently choose a panel most appropriate for that individual. Finally, we expect that as our knowledge on the subject increases many more factors and considerations are likely to enter the design and selection of diagnostic methylation marker panels.

\section{Acknowledgements}

The authors thank Julie Graham for typing. Supported by NIH HL34788.

\section{References}

1. Gohagan J, Marcus P, Fagerstrom R, Pinsky P, Kramer B and Prorok P: Baseline findings of a randomized feasibility trial of lung cancer screening with spiral CT scan vs chest radiograph: the Lung Screening Study of the National Cancer Institute. Chest 126: 114-121, 2004.

2. Jett JR and Midthun DE: Screening for lung cancer: current status and future directions: Thomas A. Neff lecture. Chest 125 : 158S-162S, 2004.

3. Parkin DM, Pisani P and Ferlay J: Global cancer statistics. CA Cancer J Clin 49: 33-64, 31, 1999.

4. van Klaveren RJ, Habbema JDF, Pedersen JH, de Koning HJ, Oudkerk M and Hoogsteden HC: Lung cancer screening by lowdose spiral computed tomography. Eur Respir J 18: 857-866, 2001.

5. Ginsberg RJ, Vokes EE and Rosenzweig K: Non-small cell lung cancer. In: Cancer: Principles and Practice of Oncology. V.T. DeVita Jr, Hellman S and Rosenberg SA (eds). 6th edition. JB Lippincott, Philadelphia, pp925-983, 2001.

6. Rom WN, Hay JG, Lee TC, Jiang Y and Tchou-Wong KM: Molecular and genetic aspects of lung cancer. Am J Respir Crit Care Med 161: 1355-1367, 2000.

7. Ries LAG, Harkins D, Krapcho M, Mariotto A, Miller BA, Feuer EJ, Clegg L, Eisner MP, Horner MJ, Howlader N, Hayat M, Hankey BF and Edwards BK (eds): SEER Cancer Statistics Review, 1975-2003. National Cancer Institute, Bethesda, MD, http://seer.cancer.gov/csr/1975_2003/, 2006.

8. Guessous I, Cornuz J and Paccaud F: Lung cancer screening: current situation and perspective. Swiss Med Wkly 137: 304-311, 2007.

9. Attwood JT, Yung RL and Richardson BC: DNA methylation and the regulation of gene transcription. Cell Mol Life Sci 59: 241-257, 2002.

10. Baylin SB and Herman JG: DNA hypermethylation in tumorigenesis: epigenetics joins genetics. Trends Genet 16: 168-174, 2000.

11. Bird A: DNA methylation patterns and epigenetic memory. Genes Dev 16: 6-21, 2002.

12. Clark SJ and Melki J: DNA methylation and gene silencing in cancer: which is the guilty party? Oncogene 21: 5380-5387, 2002.

13. Das PM and Singal R: DNA methylation and cancer. J Clin Oncol 22: 4632-4642, 2004.

14. Robertson KD and Jones PA: DNA methylation: past, present and future directions. Carcinogenesis 21: 461-467, 2000.

15. Craig JM and Bickmore WA: The distribution of $\mathrm{CpG}$ islands in mammalian chromosomes. Nat Genet 7: 376-382, 1994.

16. Wilson AS, Power BE and Molloy PL: DNA hypomethylation and human diseases. Biochim Biophys Acta 1775: 138-162, 2007.

17. Fulka H, St John JC, Fulka J and Hozak P: Chromatin in early mammalian embryos: achieving the pluripotent state. Differentiation 76: 3-14, 2008.

18. Tang WY and Ho SM: Epigenetic reprogramming and imprinting in origins of disease. Rev Endocr Metab Disord 8: 173-182, 2007.

19. Baylin SB, Belinsky SA and Herman JG: Aberrant methylation of gene promoters in cancer - concepts, misconcepts, and promise. J Natl Cancer Inst 92: 1460-1461, 2000. 
20. Issa JP, Vertino PM, Boehm CD, Newsham IF and Baylin SB Switch from monoallelic to biallelic human IGF2 promoter methylation during aging and carcinogenesis. Proc Natl Acad Sci USA 93: 11757-11762, 1996.

21. Toyota $\mathrm{M}$ and Issa JP: $\mathrm{CpG}$ island methylator phenotypes in aging and cancer. Semin Cancer Biol 9: 349-357, 1999.

22. Shi H, Wang MX and Caldwell CW: $\mathrm{CpG}$ islands: their potential as biomarkers for cancer. Expert Rev Mol Diagn 7: 519-531, 2007

23. Frey FJ: Methylation of $\mathrm{CpG}$ islands: potential relevance for hypertension and kidney diseases. Nephrol Dial Transplant 20 868-869, 2005.

24. Ballestar E, Esteller M and Richardson BC: The epigenetic face of systemic lupus erythematosus. J Immunol 176: 7143-7147, 2006.

25. Esteller M: The necessity of a human epigenome project. Carcinogenesis 27: 1121-1125, 2006

26. Bjornsson HT, Fallin MD and Feinberg AP: An integrated epigenetic and genetic approach to common human disease. Trends Genet 20: 350-358, 2004.

27. Baylin SB, Esteller M, Rountree MR, Bachman KE, Schuebel K and Herman JG: Aberrant patterns of DNA methylation, chromatin formation and gene expression in cancer. Hum Mol Genet 10: 687-692, 2001

28. Laird PW: Cancer epigenetics. Hum Mol Genet 14 (Spec No 1): R65-R76, 2005.

29. Esteller M and Herman JG: Cancer as an epigenetic disease: DNA methylation and chromatin alterations in human tumours. J Pathol 196: 1-7, 2002

30. Chilukamarri L, Hancock AL, Malik S, Zabkiewicz J, Baker JA, Greenhough A, Dallosso AR, Huang TH, Royer-Pokora B, Brown KW and Malik K: Hypomethylation and aberrant expression of the glioma pathogenesis-related 1 gene in Wilms tumors. Neoplasia 9: 970-978, 2007

31. Kim SJ, Kang HS, Chang HL, Jung YC, Sim HB, Lee KS, Ro J and Lee ES: Promoter hypomethylation of the N-acetyltransferase 1 gene in breast cancer. Oncol Rep 19: 663-668, 2008.

32. Lin Z, Thomas NJ, Bibikova M, Seifart C, Wang Y, Guo X, Wang G, Vollmer E, Goldmann T, Garcia EW, Zhou L, Fan JB and Floros J: DNA methylation markers of surfactant proteins in lung cancer. Int J Oncol 31: 181-191, 2007.

33. Baylin SB: DNA methylation and gene silencing in cancer. Nat Clin Pract Oncol 2 Suppl 1: 4-11, 2005.

34. Paluszczak J and Baer-Dubowska W: Epigenetic diagnostics of cancer - the application of DNA methylation markers. J Appl Genet 47: 365-375, 2006

35. Henrique $\mathrm{R}$ and Jeronimo $\mathrm{C}$ : Molecular detection of prostate cancer: a role for GSTP1 hypermethylation. Eur Urol 46: 660-669, 2004

36. Jeronimo C, Henrique R, Hoque MO, Ribeiro FR, Oliveira J, Fonseca D, Teixeira MR, Lopes C and Sidransky D: Quantitative RARbeta2 hypermethylation: a promising prostate cancer marker Clin Cancer Res 10: 4010-4014, 2004.

37. Tokumaru Y, Harden SV, Sun DI, Yamashita K, Epstein JI and Sidransky D: Optimal use of a panel of methylation markers with GSTP1 hypermethylation in the diagnosis of prostate adenocarcinoma. Clin Cancer Res 10: 5518-5522, 2004.

38. Fiegl H, Gattringer C, Widschwendter A, Schneitter A, Ramoni A, Sarlay D, Gaugg I, Goebel G, Muller HM, Mueller-Holzner E, Marth C and Widschwendter M: Methylated DNA collected by tampons - a new tool to detect endometrial cancer. Cancer Epidemiol Biomarkers Prev 13: 882-888, 2004.

39. Krassenstein R, Sauter E, Dulaimi E, Battagli C, Ehya H Klein-Szanto A and Cairns P: Detection of breast cancer in nipple aspirate fluid by $\mathrm{CpG}$ island hypermethylation. Clin Cancer Res 10: 28-32, 2004.

40. Szyf M, Pakneshan P and Rabbani SA: DNA methylation and breast cancer. Biochem Pharmacol 68: 1187-1197, 2004.

41. Qu G, Dubeau L, Narayan A, Yu MC and Ehrlich M: Satellite DNA hypomethylation vs. overall genomic hypomethylation in ovarian epithelial tumors of different malignant potential. Mutat Res 423: 91-101, 1999.

42. Widschwendter M, Jiang G, Woods C, Muller HM, Fiegl H Goebel G, Marth C, Muller-Holzner E, Zeimet AG, Laird PW and Ehrlich M: DNA hypomethylation and ovarian cancer biology. Cancer Res 64: 4472-4480, 2004

43. Costa FF, Paixao VA, Cavalher FP, Ribeiro KB, Cunha IW Rinck JA Jr, O'Hare M, Mackay A, Soares FA, Brentani RR and Camargo AA: SATR-1 hypomethylation is a common and early event in breast cancer. Cancer Genet Cytogenet 165: 135-143, 2006
44. Jackson K, Yu MC, Arakawa K, Fiala E, Youn B, Fiegl H, Muller-Holzner E, Widschwendter M and Ehrlich M: DNA hypomethylation is prevalent even in low-grade breast cancers. Cancer Biol Ther 3: 1225-1231, 2004.

45. Takai D, Yagi Y, Habib N, Sugimura T and Ushijima T: Hypomethylation of LINE1 retrotransposon in human hepatocellular carcinomas, but not in surrounding liver cirrhosis. Jpn J Clin Oncol 30: 306-309, 2000.

46. Chalitchagorn K, Shuangshoti S, Hourpai N, Kongruttanachok N, Tangkijvanich P, Thong-ngam D, Voravud N, Sriuranpong V and Mutirangura A: Distinctive pattern of LINE-1 methylation level in normal tissues and the association with carcinogenesis. Oncogene 23: 8841-8846, 2004

47. Weisenberger DJ, Campan M, Long TI, Kim M, Woods C Fiala E, Ehrlich M and Laird PW: Analysis of repetitive element DNA methylation by MethyLight. Nucleic Acids Res 33: 6823-6836, 2005

48. Andreasen PA, Egelund R and Petersen HH: The plasminogen activation system in tumor growth, invasion, and metastasis. Cell Mol Life Sci 57: 25-40, 2000.

49. Werb Z: ECM and cell surface proteolysis: regulating cellular ecology. Cell 91: 439-442, 1997.

50. Vlodavsky I, Goldshmidt O, Zcharia E, Metzger S, Chajek-Shaul T, Atzmon R, Guatta-Rangini Z and Friedmann Y: Molecular properties and involvement of heparanase in cancer progression and normal development. Biochimie 83: 831-839, 2001.

51. Senolt L, Grigorian M, Lukanidin E, Michel BA, Gay RE, Gay S, Pavelka K and Neidhart M: S100A4 (Mts1): is there any relation to the pathogenesis of rheumatoid arthritis? Autoimmun Rev 5: 129-131, 2006.

52. Huber RM and Stratakis DF: Molecular oncology - perspectives in lung cancer. Lung Cancer 45 (Suppl 2): 209-213, 2004

53. Mitsuuchi Y and Testa JR: Cytogenetics and molecular genetics of lung cancer. Am J Med Genet 115: 183-188, 2002.

54. Shriver SP, Bourdeau HA, Gubish CT, Tirpak DL, Davis AL, Luketich JD and Siegfried JM: Sex-specific expression of gastrin-releasing peptide receptor: relationship to smoking history and risk of lung cancer. J Natl Cancer Inst 92: 24-33, 2000.

55. Sozzi G, Sard L, De Gregorio L, Marchetti A, Musso K, Buttitta F Tornielli S, Pellegrini S, Veronese ML, Manenti G, Incarbone M, Chella A, Angeletti CA, Pastorino U, Huebner K, Bevilaqua G, Pilotti S, Croce CM and Pierotti MA: Association between cigarette smoking and FHIT gene alterations in lung cancer. Cancer Res 57: 2121-2123, 1997.

56. Thun MJ, Henley SJ and Calle EE: Tobacco use and cancer: an epidemiologic perspective for geneticists. Oncogene 21 : 7307-7325, 2002 .

57. Maggiore C, Mule A, Fadda G, Rossi ED, Lauriola L, Vecchio FM and Capelli A: Histological classification of lung cancer. Rays 29: 353-355, 2004.

58. Panani AD and Roussos C: Cytogenetic and molecular aspects of lung cancer. Cancer Lett 239: 1-9, 2006.

59. Belinsky SA, Nikula KJ, Palmisano WA, Michels R, Saccomanno G, Gabrielson E, Baylin SB and Herman JG: Aberrant methylation of p16(INK4a) is an early event in lung cancer and a potential biomarker for early diagnosis. Proc Natl Acad Sci USA 95: 11891-11896, 1998.

60. Cheng S, Gao Y, Dong X, Lu Y, An Q, Tong T and Wang Y: Molecular and cytogenetic alterations in early stage of carcinogenesis of human lung. Cancer Lett 162 (Suppl): 5-10, 2001.

61. Hung J, Kishimoto Y, Sugio K, Virmani A, McIntire DD, Minna JD and Gazdar AF: Allele-specific chromosome 3p deletions occur at an early stage in the pathogenesis of lung carcinoma. JAMA 273: 558-563, 1995.

62. Kishimoto Y, Sugio K, Hung JY, Virmani AK, McIntire DD Minna JD and Gazdar AF: Allele-specific loss in chromosome $9 \mathrm{p}$ loci in preneoplastic lesions accompanying non-small-cell lung cancers. J Natl Cancer Inst 87: 1224-1229, 1995.

63. Li ZH, Zheng J, Weiss LM and Shibata D: c-k-ras and p53 mutations occur very early in adenocarcinoma of the lung. Am J Pathol 144: 303-309, 1994.

64. Wistuba, II, Behrens C, Milchgrub S, Bryant D, Hung J, Minna JD and Gazdar AF: Sequential molecular abnormalities are involved in the multistage development of squamous cell lung carcinoma. Oncogene 18: 643-650, 1999.

65. Grote HJ, Schmiemann V and Bocking A: Molecular cytopathology of lung cancer - prevalence of genetic alterations and their role in the development of molecular biomarkers. Verh Dtsch Ges Pathol 87: 142-149, 2003. 
66. Palmisano WA, Divine KK, Saccomanno G, Gilliland FD, Baylin SB, Herman JG and Belinsky SA: Predicting lung cancer by detecting aberrant promoter methylation in sputum. Cancer Res 60: 5954-5958, 2000.

67. Burbee DG, Forgacs E, Zochbauer-Muller S, Shivakumar L, Fong K, Gao B, Randle D, Kondo M, Virmani A, Bader S, Sekido Y, Latif F, Milchgrub S, Toyooka S, Gazdar AF, Lerman MI, Zabarovsky E, White M and Minna JD: Epigenetic inactivation of RASSF1A in lung and breast cancers and malignant phenotype suppression. J Natl Cancer Inst 93: 691-699, 2001.

68. Brabender J, Usadel H, Danenberg KD, Metzger R, Schneider PM Lord RV, Wickramasinghe K, Lum CE, Park J, Salonga D, Singer J, Sidransky D, Holscher AH, Meltzer SJ and Danenberg PV: Adenomatous polyposis coli gene promoter hypermethylation in non-small cell lung cancer is associated with survival. Oncogene 20: 3528-3532, 2001

69. Tang X, Khuri FR, Lee JJ, Kemp BL, Liu D, Hong WK and Mao L: Hypermethylation of the death-associated protein (DAP) kinase promoter and aggressiveness in stage I non-small-cell lung cancer. J Natl Cancer Inst 92: 1511-1516, 2000.

70. Belinsky SA, Grimes MJ, Casas E, Stidley CA, Franklin WA, Bocklage TJ, Johnson DH and Schiller JH: Predicting gene promoter methylation in non-small-cell lung cancer by evaluating sputum and serum. Br J Cancer 96: 1278-1283, 2007.

71. Ushijima T: Detection and interpretation of altered methylation patterns in cancer cells. Nat Rev Cancer 5: 223-231, 2005.

72. Shames DS, Girard L, Gao B, Sato M, Lewis CM, Shivapurkar N, Jiang A, Perou CM, Kim YH, Pollack JR, Fong KM, Lam CL, Wong M, Shyr Y, Nanda R, Olopade OI, Gerald W, Euhus DM, Shay JW, Gazdar AF and Minna JD: A genome-wide screen for promoter methylation in lung cancer identifies novel methylation markers for multiple malignancies. PLoS Med 3: e486, 2006.

73. Yue W, Dacic S, Sun Q, Landreneau R, Guo M, Zhou W, Siegfried JM, Yu J and Zhang L: Frequent inactivation of RAMP2, EFEMP1 and Dutt 1 in lung cancer by promoter hypermethylation. Clin Cancer Res 13: 4336-4344, 2007.

74. Belinsky SA: Gene-promoter hypermethylation as a biomarker in lung cancer. Nat Rev Cancer 4: 707-717, 2004.

75. Tsou JA, Hagen JA, Carpenter CL and Laird-Offringa IA: DNA methylation analysis: a powerful new tool for lung cancer diagnosis. Oncogene 21: 5450-5461, 2002.

76. Bibikova M, Lin Z, Zhou L, Chudin E, Garcia EW, Wu B, Doucet D, Thomas NJ, Wang Y, Vollmer E, Goldmann T, Seifart C, Jiang W, Barker DL, Chee MS, Floros J and Fan JB: High-throughput DNA methylation profiling using universal bead arrays. Genome Res 16: 383-393, 2006.

77. Adorjan P, Distler J, Lipscher E, Model F, Muller J, Pelet C, Braun A, Florl AR, Gutig D, Grabs G, Howe A, Kursar M, Lesche R, Leu E, Lewin A, Maier S, Muller V, Otto T, Scholz C, Schulz WA, Seifert HH, Schwope I, Ziebarth H, Berlin K, Piepenbrock $\mathrm{C}$ and Olek A: Tumour class prediction and discovery by microarray-based DNA methylation analysis. Nucleic Acids Res 30: e21, 2002.

78. Blaser MJ, Chyou PH and Nomura A: Age at establishment of Helicobacter pylori infection and gastric carcinoma, gastric ulcer, and duodenal ulcer risk. Cancer Res 55: 562-565, 1995.

79. Kuper H, Adami HO and Trichopoulos D: Infections as a major preventable cause of human cancer. J Intern Med 248: 171-183, 2000 .

80. Shacter E and Weitzman SA: Chronic inflammation and cancer. Oncology (Williston Park) 16: 217-230, 2002.

81. Balkwill $\mathrm{F}$ and Mantovani A: Inflammation and cancer: back to Virchow? Lancet 357: 539-545, 2001.

82. Floros $\mathbf{J}$ and Phelps DS: Pulmonary surfactant protein A; structure, expression, and its role in innate host defense. In: Surfactant-Update of Intensive Care Medicine. Nakos G and Lekka M (eds). Vol. 6, University of Ioannina 6, Ioannina, pp87-102, 2002

83. Kingma PS and Whitsett JA: In defense of the lung: surfactant protein A and surfactant protein D. Curr Opin Pharmacol 6: 277-283, 2006

84. Kuroki Y, Takahashi M and Nishitani C: Pulmonary collectins in innate immunity of the lung. Cell Microbiol 9: 1871-1879, 2007.

85. Phelps DS: Surfactant regulation of host defense function in the lung: a question of balance. Pediatr Pathol Mol Med 20: 269-292, 2001
86. Atochina EN, Beck JM, Preston AM, Haczku A, Tomer Y, Scanlon ST, Fusaro T, Casey J, Hawgood S, Gow AJ and Beers MF: Enhanced lung injury and delayed clearance of Pneumocystis carinii in surfactant protein A-deficient mice: attenuation of cytokine responses and reactive oxygen-nitrogen species. Infect Immun 72: 6002-6011, 2004.

87. Atochina EN, Gow AJ, Beck JM, Haczku A, Inch A, Kadire H, Tomer Y, Davis C, Preston AM, Poulain F, Hawgood S and Beers MF: Delayed clearance of pneumocystis carinii infection, increased inflammation, and altered nitric oxide metabolism in lungs of surfactant protein-D knockout mice. J Infect Dis 189: $1528-1539,2004$.

88. Harrod KS, Trapnell BC, Otake K, Korfhagen TR and Whitsett JA: SP-A enhances viral clearance and inhibits inflammation after pulmonary adenoviral infection. Am J Physiol 277: L580-L588, 1999.

89. Kremlev SG and Phelps DS: Surfactant protein A stimulation of inflammatory cytokine and immunoglobulin production. Am J Physiol 267: L712-L719, 1994.

90. Kremlev SG and Phelps DS: Effect of SP-A and surfactant lipids on expression of cell surface markers in the THP-1 monocytic cell line. Am J Physiol 272: L1070-L1077, 1997.

91.Kremlev SG, Umstead TM and Phelps DS: Effects of surfactant protein A and surfactant lipids on lymphocyte proliferation in vitro. Am J Physiol 267: L357-L364, 1994

92. Kremlev SG, Umstead TM and Phelps DS: Surfactant protein A regulates cytokine production in the monocytic cell line THP-1. Am J Physiol 272: L996-L1004, 1997.

93. Lekkala M, LeVine AM, Linke MJ, Crouch EC, Linders B, Brummer E and Stevens DA: Effect of lung surfactant collectins on bronchoalveolar macrophage interaction with Blastomyces dermatitidis: inhibition of tumor necrosis factor alpha production by surfactant protein D. Infect Immun 74: 4549-4556, 2006

94. Crowther JE, Kutala VK, Kuppusamy P, Ferguson JS Beharka AA, Zweier JL, McCormack FX and Schlesinger LS: Pulmonary surfactant protein a inhibits macrophage reactive oxygen intermediate production in response to stimuli by reducing NADPH oxidase activity. J Immunol 172: 6866-6874, 2004.

95. Pasula R, Wright JR, Kachel DL and Martin WJ II: Surfactant protein A suppresses reactive nitrogen intermediates by alveolar macrophages in response to Mycobacterium tuberculosis. J Clin Invest 103: 483-490, 1999.

96. Palaniyar N, Clark H, Nadesalingam J, Hawgood S and Reid KB: Surfactant protein D binds genomic DNA and apoptotic cells, and enhances their clearance, in vivo. Ann NY Acad Sci 1010: $471-475,2003$

97. Schagat TL, Wofford JA and Wright JR: Surfactant protein A enhances alveolar macrophage phagocytosis of apoptotic neutrophils. J Immunol 166: 2727-2733, 2001.

98. Vandivier RW, Ogden CA, Fadok VA, Hoffmann PR, Brown KK, Botto M, Walport MJ, Fisher JH, Henson PM and Greene KE: Role of surfactant proteins A, D, and Clq in the clearance of apoptotic cells in vivo and in vitro: calreticulin and CD91 as a common collectin receptor complex. J Immunol 169: 3978-3986, 2002.

99. Brinker KG, Garner H and Wright JR: Surfactant protein A modulates the differentiation of murine bone marrow-derived dendritic cells. Am J Physiol Lung Cell Mol Physiol 284: L232-L241, 2003.

100. Brinker KG, Martin E, Borron P, Mostaghel E, Doyle C, Harding CV and Wright JR: Surfactant protein D enhances bacterial antigen presentation by bone marrow-derived dendritic cells. Am J Physiol Lung Cell Mol Physiol 281: L1453-L1463, 2001.

101. Korfhagen TR, Bruno MD, Ross GF, Huelsman KM, Ikegami M, Jobe AH, Wert SE, Stripp BR, Morris RE, Glasser SW, Bachurski CJ, Iwamoto HS and Whitsett JA: Altered surfactant function and structure in SP-A gene targeted mice. Proc Natl Acad Sci USA 93: 9594-9599, 1996.

102. Ikegami M, Jobe AH, Whitsett J and Korfhagen T: Tolerance of SP-A-deficient mice to hyperoxia or exercise. J Appl Physiol 89: 644-648, 2000

103. LeVine AM, Whitsett JA, Gwozdz JA, Richardson TR, Fisher JH, Burhans MS and Korfhagen TR: Distinct effects of surfactant protein A or D deficiency during bacterial infection on the lung. J Immunol 165: 3934-3940, 2000.

104. Li G, Siddiqui J, Hendry M, Akiyama J, Edmondson J, Brown C, Allen L, Levitt S, Poulain F and Hawgood S: Surfactant protein-A - deficient mice display an exaggerated early inflammatory response to a beta-resistant strain of influenza A virus. Am J Respir Cell Mol Biol 26: 277-282, 2002. 
105. Botas C, Poulain F, Akiyama J, Brown C, Allen L, Goerke J, Clements J, Carlson E, Gillespie AM, Epstein C and Hawgood S: Altered surfactant homeostasis and alveolar type II cell morphology in mice lacking surfactant protein D. Proc Natl Acad Sci USA 95: 11869-11874, 1998.

106. Ikegami M, Korfhagen TR, Bruno MD, Whitsett JA and Jobe AH: Surfactant metabolism in surfactant protein A-deficient mice. Am J Physiol 272: L479-L485, 1997.

107. DiAngelo S, Lin Z, Wang G, Phillips S, Ramet M, Luo J and Floros J: Novel, non-radioactive, simple and multiplex PCRcRFLP methods for genotyping human SP-A and SP-D marker alleles. Dis Markers 15: 269-281, 1999.

108. Floros $\mathrm{J}$ and Hoover RR: Genetics of the hydrophilic surfactant proteins A and D. Biochim Biophys Acta 1408: 312-322, 1998

109. Huang W, Wang G, Phelps DS, Al-Mondhiry H and Floros J: Human SP-A genetic variants and bleomycin-induced cytokine production by THP-1 cells: effect of ozone-induced SP-A oxidation. Am J Physiol Lung Cell Mol Physiol 286: L546-L553, 2004.

110. Wang G, Phelps DS, Umstead TM and Floros J: Human SP-A protein variants derived from one or both genes stimulate TNFalpha production in the THP-1 cell line. Am J Physiol Lung Cell Mol Physiol 278: L946-L954, 2000.

111. Wang G, Umstead TM, Phelps DS, Al-Mondhiry H and Floros J: The effect of ozone exposure on the ability of human surfactant protein a variants to stimulate cytokine production. Environ Health Perspect 110: 79-84, 2002.

112. Mikerov AN, Umstead TM, Gan X, Huang W, Guo X, Wang G, Phelps DS and Floros J: Impact of ozone exposure on the phagocytic activity of human surfactant protein A (SP-A) and SP-A variants. Am J Physiol Lung Cell Mol Physiol 294: L121-L130, 2008

113. Mikerov AN, Umstead TM, Huang W, Liu W, Phelps DS and Floros J: SP-A1 and SP-A2 variants differentially enhance association of Pseudomonas aeruginosa with rat alveolar macrophages. Am J Physiol Lung Cell Mol Physiol 288: L150-L158, 2005.

114. Mikerov AN, Wang G, Umstead TM, Zacharatos M, Thomas NJ, Phelps DS and Floros J: Surfactant protein A2 (SP-A2) variants expressed in $\mathrm{CHO}$ cells stimulate phagocytosis of Pseudomonas aeruginosa more than do SP-A1 variants. Infect Immun 75 1403-1412, 2007.

115. Wang G, Bates-Kenney SR, Tao JQ, Phelps DS and Floros J: Differences in biochemical properties and in biological function between human SP-A1 and SP-A2 variants, and the impact of ozone-induced oxidation. Biochemistry 43: 4227-4239, 2004.

116. Oberley RE and Snyder JM: Recombinant human SP-A1 and SP-A2 proteins have different carbohydrate-binding characteristics. Am J Physiol Lung Cell Mol Physiol 284 L871-L881, 2003.

117. Tagaram HR, Wang G, Umstead TM, Mikerov AN, Thomas NJ, Graff GR, Hess JC, Thomassen MJ, Kavuru MS, Phelps DS and Floros J: Characterization of a human surfactant protein A1 (SP-A1) gene-specific antibody; SP-A1 content variation among individuals of varying age and pulmonary health. Am J Physiol Lung Cell Mol Physiol 292: L1052-L1063, 2007.

118. Hoover RR and Floros J: SP-A 3'-UTR is involved in the glucocorticoid inhibition of human SP-A gene expression. Am J Physiol 276: L917-L924, 1999.

119. Hoover RR, Pavlovic J and Floros J: Induction of AP-1 binding to intron 1 of SP-A1 and SP-A2 is implicated in the phorbol ester inhibition of human SP-A promoter activity. Exp Lung Res 26: 303-317, 2000

120. Wang G, Guo X and Floros J: Human SP-A 3'-UTR variants mediate differential gene expression in basal levels and in response to dexamethasone. Am J Physiol Lung Cell Mol Physiol 284: L738-L748, 2003.
121. Wang G, Guo X and Floros J: Differences in the translation efficiency and mRNA stability mediated by 5'-UTR splice variants of human SP-A1 and SP-A2 genes. Am J Physiol Lung Cell Mol Physiol 289: L497-L508, 2005.

122. Bejarano PA, Baughman RP, Biddinger PW, Miller MA, Fenoglio-Preiser C, al-Kafaji B, Di Lauro R and Whitsett JA: Surfactant proteins and thyroid transcription factor- 1 in pulmonary and breast carcinomas. Mod Pathol 9: 445-452, 1996.

123. Goldmann T, Galle J, Wiedorn KH, Deutschbein ME, Neuhaus M, Branscheid D and Vollmer E: Diagnostic value of immunohistochemically detected surfactant - apoprotein-A in malignant tumors located in the lungs: report of two cases. Ann Diagn Pathol 5: 84-90, 2001.

124. Linnoila RI, Mulshine JL, Steinberg SM and Gazdar AF: Expression of surfactant-associated protein in non-small-cell lung cancer: a discriminant between biologic subsets. J Natl Cancer Inst Monogr, pp61-66, 1992.

125. O'Reilly MA, Gazdar AF, Morris RE and Whitsett JA: Differential effects of glucocorticoid on expression of surfactant proteins in a human lung adenocarcinoma cell line. Biochim Biophys Acta 970: 194-204, 1988.

126. Saitoh H, Shimura S, Fushimi T, Okayama H and Shirato K: Detection of surfactant protein-A gene transcript in the cells from pleural effusion for the diagnosis of lung adenocarcinoma. Am J Med 103: 400-404, 1997.

127. Tsutsumida H, Goto M, Kitajima S, Kubota I, Hirotsu Y and Yonezawa S: Combined status of MUC1 mucin and surfactant apoprotein A expression can predict the outcome of patients with small-size lung adenocarcinoma. Histopathology 44: $147-155,2004$

128.Zamecnik J and Kodet R: Value of thyroid transcription factor-1 and surfactant apoprotein $\mathrm{A}$ in the differential diagnosis of pulmonary carcinomas: a study of 109 cases. Virchows Arch 440: 353-361, 2002.

129. Chong IW, Chang MY, Chang HC, Yu YP, Sheu CC, Tsai JR, Hung JY, Chou SH, Tsai MS, Hwang JJ and Lin SR: Great potential of a panel of multiple hMTH1, SPD, ITGA11 and COL11A1 markers for diagnosis of patients with non-small cell lung cancer. Oncol Rep 16: 981-988, 2006.

130. Dessy E, Falleni M, Del Curto B, Braidotti P and Pietra GG: Surfactant protein and thyroid transcription factor 1 in pleuropulmonary neoplasia. Immunohistochemical study. Pathologica 92: 496-502, 2000.

131. Shijubo N, Honda Y, Fujishima T, Takahashi H, Kodama T, Kuroki Y, Akino T and Abe S: Lung surfactant protein-A and carcinoembryonic antigen in pleural effusions due to lung adenocarcinoma and malignant mesothelioma. Eur Respir J 8: 403-406, 1995

132. Seifart C, Lin HM, Seifart U, Plagens A, DiAngelo S, von Wichert P and Floros J: Rare SP-A alleles and the SP-A1-6A(4) allele associate with risk for lung carcinoma. Clin Genet 68: 128-136, 2005.

133. Jiang F, Yin Z, Caraway NP, Li R and Katz RL: Genomic profiles in stage I primary non small cell lung cancer using comparative genomic hybridization analysis of cDNA microarrays. Neoplasia 6: 623-635, 2004.

134. Jiang F, Caraway NP, Nebiyou Bekele B, Zhang HZ, Khanna A, Wang H, Li R, Fernandez RL, Zaidi TM, Johnston DA and Katz RL: Surfactant protein A gene deletion and prognostics for patients with stage I non-small cell lung cancer. Clin Cancer Res 11: 5417-5424, 2005

135. Katsenelson NS, Shurin GV, Bykovskaia SN, Shogan J and Shurin MR: Human small cell lung carcinoma and carcinoid tumor regulate dendritic cell maturation and function. Mod Pathol 14: 40-45, 2001 